Article

\title{
Management of Postindustrial Heritage in Urban Revitalization Processes
}

\author{
Agnieszka Konior and Weronika Pokojska *iD \\ Faculty of Management and Social Communication, Institute of Culture, Jagiellonian University, \\ 30-348 Cracow, Poland; agn.konior@uj.edu.pl \\ * Correspondence: weronika.pokojska@uj.edu.pl
}

Received: 15 May 2020; Accepted: 17 June 2020; Published: 19 June 2020

\begin{abstract}
The paper presents the results of original research on the use of heritage in revitalization processes. The study was conducted on selected postindustrial areas in Poland. The analysis is based on research conducted mainly with qualitative methods, including desk research, field query, participating observation, and in-depth interviews with selected stakeholders of postindustrial heritage. The purpose of the article is to indicate that cultural heritage is used in the regeneration processes of postindustrial areas. We prove that cultural heritage is not a separate category present in the revitalization process, but it is visible in spatial, social, and economic aspects of this process. To illustrate this, we provide numerous examples that we identified during research. In summary, we present the benefits of using cultural heritage in the revitalization process.
\end{abstract}

Keywords: urban revitalization; industrial heritage; heritage management; heritage sustainability

\section{Introduction}

Revitalization is a long-term process aimed at rescuing an urban area out of a crisis. This change concerns both the material tissue-buildings, public spaces, green areas-and intangible elements in economic, social, or cultural spheres [1]. The latter includes the use of heritage. Among the different benefits of revitalization, experts mention the improvement of a city or area image, the help in developing a sense of community, the support in reusing existing buildings and preventing their further dilapidation, the increase in employment and business activation, the fostering of the unique character of a community and its history: "Visible signs of the past can be retained and stories can be passed on to the next generation" [2]. Thus, revitalization is a comprehensive undertaking, which requires cooperation at many levels and areas, but also one that considers the needs and expectations of many stakeholders.

After 1989, many state-owned enterprises in Poland were liquidated because they were unable to withstand market competition. Among them were mines, factories, steel mills, and textile factories [3]. This resulted in the degradation of cities not only in the spatial sense (many empty postindustrial spaces), but also in the social and the economic sense (unemployment, crime, problems with the adaptation to the new, capitalistic reality) [4]. There was a great need to revitalize postindustrial areas, which was not immediately possible due to other priorities. Game-changing opportunities appeared after 2004, i.e., after Poland's accession to the European Union, which was followed by a transfer of funds and know-how [5,6].

Over the past 15 years, the scale of revitalization of Polish cities has grown significantly. Initially, this process was mostly spatial, but currently many increasingly emphasize its social dimension [7,8]. In 2015, a special legal act was established — the Revitalization Act [9] — which gave power to local governments in the form of management tools. From this perspective, the study of urban revitalization processes in Poland appears highly significant, especially in the context of cities' sustainable development and the 
use of cultural heritage in these processes. Hence, postindustrial areas constitute a significant part of all areas subject to revitalization. After analyzing over 200 Polish local revitalization programs, Jarczewski and Kuryło [10] calculated that in $41.5 \%$ of the examined cities the area of revitalization was established in areas with, among other things, an industrial and component function; on average, they constituted almost $17 \%$ of areas subject to revitalization.

Industrial heritage is a very specific type of heritage, which consists of the remains of industrial culture [11] that have "historical, technological, social, architectural or scientific value." These may include buildings, machinery, workshops, factories, warehouses, mines, transport infrastructure, and places of social activity related to industry: residential architecture, places of religious worship or education [12]. Industrial heritage can take many sizes and forms. However, it is rarely limited to one object or area; a single machine is just a part of a larger process. Often the manifestation of industrial heritage is a series of several spatially connected places that together form the industrial landscape. A production line illustrates how the organization of production looked like, what technologies were used to transform resources into goods, how they were made available on the market, and how the whole process affected the environment. The industrial landscape is a kind of cultural landscape that has been transformed by humans due to progressive industrialization [13].

Industrial heritage is also a collection of customs, practices, and artifacts shaped by work in a given organization. It was often an element consolidating a particular community, whose members came to work from various places. They enriched the local heritage with their own customs but also adopted traditions from their workplace (e.g., vocabulary related to their work, celebration of holidays). Affelt [14] emphasizes that industrial heritage also includes the intangible sphere related to the operation of a plant: "technological knowledge in the field of craft and industrial production and know-how skills"; or, "ways of factory management, production management, organization and quality control." As Handszuh [15] writes, industrial heritage is "also about diligence, entrepreneurship and creativity." It is about aspects from the past that still are interesting and may contribute to present and future lifestyles. Cossons [16] (p. 9) believes similarly, as he writes that next to historical or technological values, industrial heritage is of considerable importance in a broader context; after all, the latter covers social and cultural aspects in people's lives, is related to their history and identity. This may apply to the entire industry sector, a specific enterprise, and also to the individual's specific skills. On the one hand, industrial heritage-and heritage in general—allows us to build identity and also to gain recognition. To summarize, we may say that there is industrial heritage sensu stricto-e.g., machinery and postindustrial buildings—and sensu largo, which includes all indirect relations to the industrial past of the place [17].

Compared to other manifestations of heritage in the general consciousness, industrial heritage has only been recognized and considered valuable for a relatively short time. As Cossons [16] (p. 7-8) notes, just as the industrial revolution dramatically affected the fate of humanity, so did the downfall of the industry following radical changes. After the decline of a mine or steel mill, related estates and communities remain, still retaining memories, maintaining relationships and pride related to belonging to a workplace $[16,18]$. Hence, people deemed it necessary to find new solutions and ways to use postindustrial areas, not only to recover useless spaces in this form but also, above all, to give a new sense of human existence previously determined by the industrial plant. For example, this process can now be observed in Detroit, which is slowly regaining balance after the collapse of the industry, which resulted in a terrible economic and social situation [19].

Moreover, we should notice that there are many similarities between the revitalization process and heritage management. Both can be defined as change management. Furthermore, both processes are continuous: in order for the legacy to be alive and seen as necessary, heritage must undergo constant changes. Similarly, in the case of revitalization, even after conducting key investments and implementing major projects, one must monitor and conduct supporting activities in the area so that it does not degrade again. Cultural heritage and revitalization relate not only to material aspects (tangible heritage/spatial revitalization) but also to immaterial (intangible heritage/social 
revitalization), and they have an economic dimension. We should always keep in mind that tangible and intangible heritage is indivisible: "The built environment carries important meanings from one generation to the next, and serves as a one repository of cultural meanings" [20] (p. 65). Moreover, the management of both processes should be undertaken in a creative way, each time adapted to local specificity.

Revitalization and cultural heritage are linked to sustainable development, as some researchers even state that culture is the "underlying dimension of sustainability" [21] (p. 175), which is visible in strategic documents on the international level [22] (p. 85). For example, the Faro Convention states: "the conservation of cultural heritage and its sustainable use have human development and quality of life as their goal" [23]. Furthermore, the United Nations' global development program in 2015

situated cultural practices, cultural life and material culture at the heart of its Sustainable Development Goals (SDG). Approaching and conceptualizing development beyond economic growth has allowed policymakers as well as development organisations, professionals and experts to see how identity (collective and individual), heritage, cultural sites and cultural expressions function as drivers and enablers in development strategies both locally and globally. [24] (p. 559)

As Erlewein [22] (p. 88) states, the three-pillar approach to sustainable development (economic, social, environmental) is currently understood as a dynamic relationship of dimensions "mutually interacting and impacting on each other," rather than a static model. The extended concept of the four-pillar approach adds the aspect of culture as an independent factor to sustainable development: "Cultural sustainability here is [ ... ] integrated on an equal basis with the other three dimensions. This approach highlights culture as (re)source and considers components of culture to include heritage, identity, memory, creativity, human knowledge and skills, cultural practices, lifestyles, value systems and diversity, among others" [22] (p. 89).

Taken together, the two processes-heritage management and revitalization-contribute to the rational use of available resources for the sake of future generations. "A sustainable conservation is essentially able to meet the needs of the present generation by generating both sufficient support for the local business and service sector and greater social equity, without compromising the future generations' access to such historic-cultural resources" [25] (p. 195). A report prepared by English Heritage indicates why the use of heritage in the revitalization process reflects the idea of sustainable development. Adaptation of objects to new functions allows us to preserve the identity and character of the place, and also creates the possibility of creating new cultural events that build a sense of community. Revitalization also contributes to the maintenance of existing companies and creates new jobs based on local heritage by increasing the attractiveness of the place. English Heritage also points to the fact that the adaptation of historic buildings to new functions-instead of demolishing them-contributes to the reduction of greenhouse gas emissions and problems with waste disposal [26]. The authors of another study emphasize that old buildings are the energy of the past stored in a form that awaits reinforcement and reuse [27] (p. 270).

The arguments presented above indicate that revitalization and heritage have many common features, and their interrelationships go far beyond the conservation of historic buildings inscribed in revitalization programs. The use of heritage in revitalization cannot be treated as a development barrier but as a significant potential of a place. Sometimes, in the name of efficiency or profitability, investors resign from adapting historic buildings, considering these processes too difficult and complicated to carry out and the objects themselves too expensive to maintain [28]. Meanwhile, research by English Heritage indicates that the costs of renovating and maintaining historic buildings are significantly lower than those of constructing new buildings [29].

The main goal of this paper is to examine the role of cultural heritage in the revitalization processes of postindustrial spaces in selected Polish cities. We focus on this particular topic, as we noticed a worthwhile research gap. In theoretical studies, there is always a suggestion to use heritage and include 
the local community in the revitalization process, but there are no sources in Poland that describe what exactly is being used, and how.

\section{Materials and Methods}

The article is based on original research conducted in 2015-2018, which addressed the research questions below:

1. How are heritage resources used in the revitalization process (in spatial, social, and economic aspects)?

2. What are the benefits of using heritage in postindustrial revitalization processes?

Five case studies were selected for the analysis (Table 1). The most important selection criterion was the postindustrial and historic character of the area. Furthermore, the revitalization of the space had to start no later than 2008 (at least 10 years before the end of the research). This allowed us to observe the first effects due to the advanced phase of the process and analyze the strategic and tactical documents covering a longer period. The selected case studies are very diverse in terms of location and type of industrial activity in the past. We describe them below.

Table 1. Selected case studies.

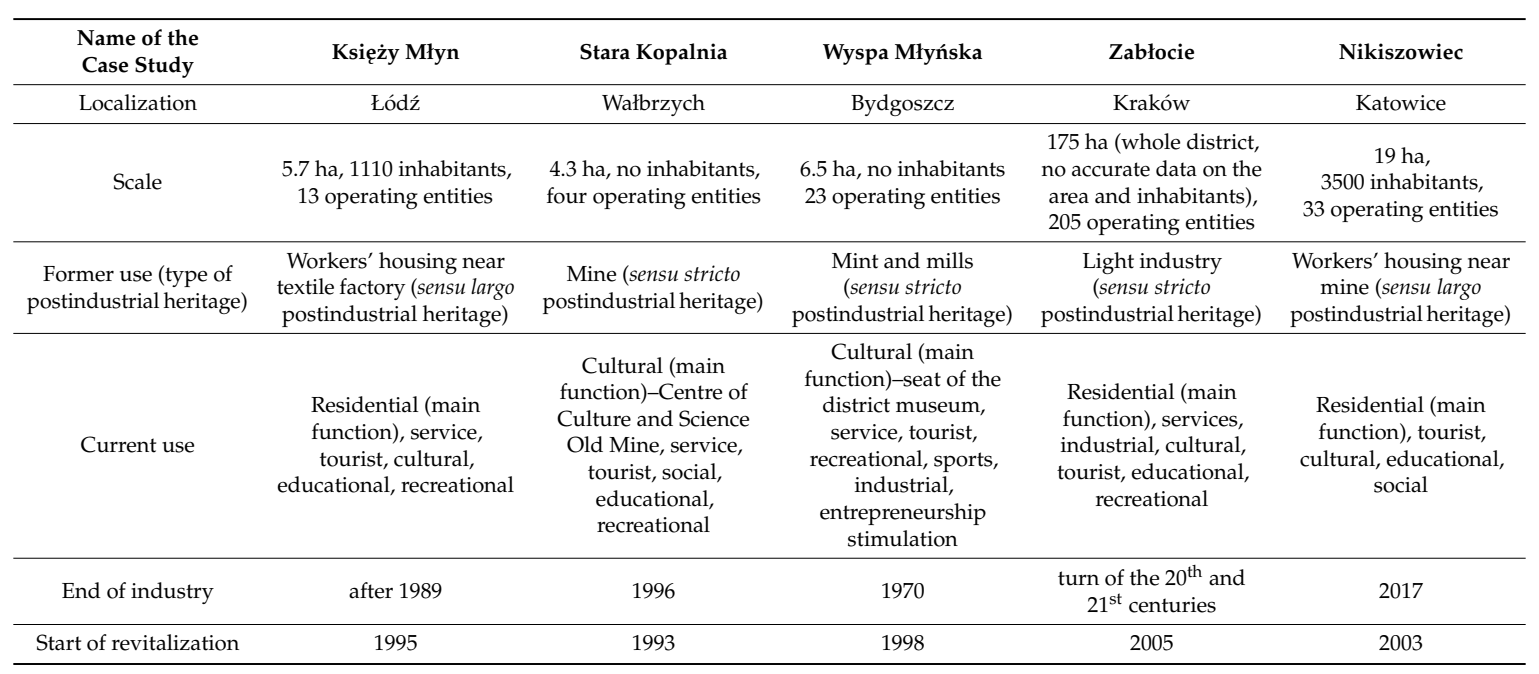

The Księży Młyn complex in Łódź was built at the turn of the nineteenth and twentieth centuries and consisted of three parts: a spinning mill, a factory owner's villa, and a workers' housing estate (only the latter was chosen for the analysis because it was covered by revitalization plans). According to experts, it is one of the most interesting examples of residential and industrial monuments on a European scale [30]. Approximately 2000 people can live there, mainly the best-qualified employees occupying the highest positions in the enterprise [31]. Through the place of residence, not only professional but also social and family ties with the workplace were created [32]. The property was nationalized after the Second World War. After 1989, production facilities also limited their activities to shut down completely over time.

Stara Kopalnia is the only preserved postindustrial complex related to coal mining and its processing in Wałbrzych. Coal has been mined in this area since the fifteenth century, although the most dynamic development was in the 1860s. Then, a deep mine and two shafts were gradually built, along with a boiler room, a workshop, a forge, a cloakroom, and a bathhouse. A sorting plant, a scrubber, and a coking plant were also established for coal processing [33]. After the Second World War, Wałbrzych became Polish territory. Citizens from former eastern Polish lands were brought in place of the German-speaking population. As researchers note [34], in these areas it is difficult to point to traditions or customs connecting all. However, mining has become a factor constituting the sense of 
local identity. In the period after the Second World War the economy was largely based on mining, but in the new market reality after 1989 the mines proved unprofitable, so the Minister of Industry in 1990 decided that the Wałbrzych mining plant was to be liquidated. The last coal cart left Stara Kopalnia in 1996 [35].

Wyspa Młyńska is a postindustrial area located in the center of Bydgoszcz on the Brda River. It is an example of a unique symbiosis of cultural and natural values [36] (p. 4). In 1364, the King of Poland granted Bydgoszcz location privileges and the right to mint coins and set up mills [37,38]. These two types of industries influenced the later history of the island. The mint was a complex of buildings operating intermittently until the end of the seventeenth century [36] (pp. 5-6). In the eighteenth century, in connection with the construction of the Bydgoszcz Canal, mills and granaries were built on Wyspa Młyńska. Several buildings out of the entire complex have survived to modern times. Some of them have a wooden half-timbered structure characteristic of Prussian buildings, filled with brick (often bleached), covered with ceramic tiles. After the Second World War Wyspa Młyńska still had industrial functions, mainly related to milling. In 1936 a marina for the Military Sports Club was built [39] (p. 36). The mill activity was terminated in the 1970s. Postindustrial facilities were gradually transferred to the ownership or use of the District Museum in Bydgoszcz [36] (p. 6).

The industrial development of the Zabłocie district in Krakow occurred at the turn of the nineteenth and twentieth centuries. According to researchers, geological and geographical conditions, location, natural resources, and the potential of brave entrepreneurial people contributed to the fact that Zabłocie became the industrial base for Krakow [40] (p. 52). There were many light industry plants in this area, including a mill and a bakery, a municipal slaughterhouse, glassworks, forges, factories producing chocolate, soap, perfume, vodka, leather, umbrella, roof tiles, cash registers, scales, and wire products [41]. During the Second World War, an enamel dish factory operating in Zabłocie was managed by Oskar Schindler whose story inspired the movie Schindler's List, directed by Steven Spielberg. Some of these factories produced supplies for the needs of the Third Reich and used a labor force from the Kraków-Płaszów labor camp. After the Second World War the production and railroad transport was significantly expanded; basically every factory had its own railway siding [42]. In the last decade of the twentieth century many plants were closed or moved, which contributed to a significant degradation of the area [43].

Nikiszowiec is a workers' housing in Katowice built in 1911-1919 for the needs of workers from a nearby mine. It consists of nine compact, highly aesthetic blocks of flats. For its time it was characterized by a high housing standard, with public utilities such as a church, a laundry, a mangle, a post office, shops, a restaurant, a photo atelier, schools, a hospital, an orphanage. From the beginning the estate was canalized and electrified, a free railway operated between the mine and the estate [44]. Intensive cultural and social activities were conducted also after the Second World War. In the early 1990s, there was a crisis in the mining industry that not only significantly affected the number of employees but also reduced funds for investment in housing resources and social activities [45]. In 2018, the nearby mine stopped working [46]. Researchers [47] (p. 41) believe that the compact and isolated structure of the buildings contributed to the fact that habits and traditions are still being cultivated in Nikiszowiec, which makes it an incubator for the identity of the local community. For example, a large number of Nikiszowiec residents use dialect on a daily basis and jointly celebrate local holidays.

For each case study, we conducted an analysis of the existing data (desk research). Overall, 26 strategic and tactical documents regarding the revitalized areas (for example, Local Revitalization Programs) were identified, along with other documents connected with the case studies (scientific studies, press releases, and other sources). Based on the field query conducted within the areas designated for revitalization, entities operating there were also identified. During the next stage of the research, we analyzed websites of these entities-especially data included in the "about us" tab-in terms of whether and how they present their cultural heritage. When the entities referred to cultural heritage, we then also examined their activities in this area, based on websites and social 
media profiles. Another research method used was participatory observation, conducted on both a daily basis and during festivals.

Moreover, we conducted partially structured in-depth interviews with heritage and revitalization stakeholders. They were carried out in 2015-2018, with 43 interlocutors. At least one interview at each of the selected sites was conducted with the following stakeholder groups:

- heirs (HE): long-term residents or former factory workers;

- $\quad$ experts (EX): monument protection professionals;

- local authorities (LA): managing the revitalization processes;

- representatives of cultural and educational organizations (CE);

- local activists and representatives of non-governmental organizations (NGO);

- local entrepreneurs (LE).

After the transcription of all interviews, the research material was anonymized and coded. Interviews with media representatives were studiously avoided because they only occasionally dealt with heritage and revitalization, although there were interlocutors who incidentally also played such roles. Tourists are a group that strongly influences revitalization, but they were not interviewed; incidentally met individuals would not have a good view of the whole revitalization process. Nevertheless, the subject appeared large enough for further, large-scale research.

\section{Results}

\subsection{The Use of Heritage Resources in Postindustrial Space Revitalization}

Heritage resources (both tangible and intangible) can be used in urban revitalization processes in multiple ways. Referring to the previously indicated four-pillar approach to sustainable development (using environmental, social, economic, and cultural dimensions) [22] (p. 89), we propose its modification. In our opinion culture is not a separate pillar, but it can be an important part of each of the other three. Therefore, symbolically, culture can be represented as a roof stretched over the pillars. Translating this model into the subject of the article, we indicate that cultural heritage-which is part of culture [48] (p. 18) — can be used in the revitalization process in three dimensions: environmental, social, and economic (Figure 1). The proposed division is arbitrary but indicates that the use of cultural heritage in urban revitalization is not limited only to aspects related to the renovation and conservation of monuments, but also takes into account intangible aspects. The results of the research are summarized in Table 2.

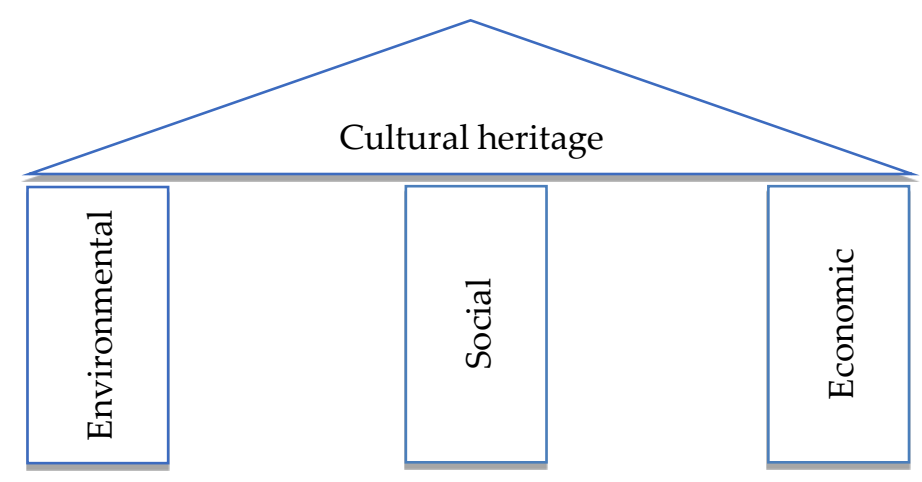

Figure 1. Approach to revitalization using cultural heritage. 
Table 2. The management of cultural heritage resources in urban revitalization.

\begin{tabular}{|c|c|c|}
\hline Spatial Aspects & Social Aspects & Economic Aspects \\
\hline $\begin{array}{l}\text { The adaptation of } \\
\text { postindustrial objects for: } \\
\text { - } \quad \text { cultural and } \\
\text { - } \quad \text { social purposes } \\
\text { - } \quad \text { residential purposes } \\
\text { - } \quad \text { New buildings purposes } \\
\text { the local heritage } \\
\text { - Simulacra } \\
\text { Heritage in public space: } \\
\text { - } \quad \text { topographic names } \\
\text { - } \quad \text { relics of } \\
\text { - } \quad \text { tangible heritage } \\
\text { - } \quad \text { outdoor exhibitions } \\
\text { - } \quad \text { places of activity } \\
\quad \text { and recreation }\end{array}$ & $\begin{array}{ll}\text { - } & \text { Lectures and presentations } \\
\text { - } & \text { Exhibitions: } \\
& -\quad \text { historical } \\
-\quad \text { art } \\
\text { - } & \text { Corkshops } \\
\text { - } & \text { Festivals and } \\
\text { - } & \text { recurring events } \\
\text { Other events }\end{array}$ & $\begin{array}{ll}\text { - } & \text { Tourist services } \\
\text { - } & \text { Food services } \\
\text { - } & \text { Hotel services and } \\
\text { - } & \text { apartments for rent } \\
\text { - } & \text { Cuuvenirs } \\
& \text { Cultural route }\end{array}$ \\
\hline
\end{tabular}

\subsubsection{Environmental Dimensions}

The first under consideration was the revitalization of space. It is the most visible and common operation. Hence, in most cases, it was the first step in the urban revitalization process. However, actions in revitalized areas cannot be limited to this. Even the most beautifully revitalized space will not be vivid without users and whatever provides them with a livelihood. Mostly in postindustrial areas there is no possibility to resume or maintain industrial activity in its historical form, even if only on a very limited scale (e.g., manufactories or small-scale enterprises). Therefore, a large number of buildings await reframing. These buildings usually are large in scale, offer many adaptation possibilities, and have a unique charm. Taking the above into consideration objects are readily adapted for the following purposes: cultural (museums, clubs, concert and sports halls, theatres, culture centers, meeting places, NGO offices); residential (lofts for individual use and for rent, halls of residence); service (restaurants, hotels, shops, schools and universities, art galleries, bookstores, tourist service points, entrepreneurship development centers).

A good example of the renovation of postindustrial buildings and their partial repurposing was the revitalization of the workers' housing at Księży Młyn. The majority of apartments are council flats; they were totally renovated by the local municipality. After the renovation, residents could return to their apartments or receive a replacement. Most decided to return because they felt connected with the place. The least attractive places to live-located on the ground floor of a busy street-were transformed into ateliers for artists. What was a disadvantage for the residents was an advantage for creative entrepreneurs. The artists not only attracted a new audience to the estate but also ran a local café, organized workshops for residents, and created artistic projects in the space of the estate. The renovation of buildings and their use not only for residential functions but also for cultural, social, and service-related activities contributed to the multifaceted revitalization of the area.

The research distinguished the following strategies among the measures aimed at adapting industrial facilities:

- securing the object, searching for a concept, and seeking financial resources for its further development: emphasis on preserving the authenticity of the object;

- keeping a part or the whole object unchanged to show the production process: emphasis on the authenticity of the object and the preservation of its spirit; 
- changing the function of the object while maintaining the existing tissue: emphasis on functionality and renovation;

- transforming part or all of the object, adding new elements: emphasis on functionality and creating a new quality of architecture, "icons."

Each of these strategies has different goals. The easiest way to protect monuments is to secure them without opening to the public. This action in the long run can contribute to the destruction rather than the survival of a monument; an object that is not needed does not find its guardians. In the case of industrial heritage management, it is important to find such functions that will contribute to the survival of the object while maintaining its authenticity, as some of the interlocutors said:

Some type of transformation must be allowed in historic buildings. For an object to live-if it changes its functions-it must be slightly changed, there is no other way, but you need to find the most important values that prove that the building is a historic object and its most valuable parts must remain. [EX_01]

It is known that the adaptation of a historic object is associated with the necessity of changes that result from functions, changes in functions, and new times. It seems to me that it was quite easy here, because most of the objects were long ago intended for museum functions ... Of course, one would like to petrify, leave everything the same, just ... leave it in a historical form, but these new functions always require some changes. [EX_03]

Our research showed that a good way to preserve industrial heritage is to change it into an industry museum and preserve the equipment. This allows us to protect heritage and adapt it to modern purposes, with little intervention in the historic tissue. However, we are unable to transform all monuments into museums. It is necessary to think about what will best meet the needs of the local community in the long term. But even the adaptation of the object for museum purposes entails changes in historic tissue-not only positive. An example can be Stara Kopalnia in Wałbrzych, where the old mine was transformed into a museum. The preservation of post-mining buildings together with their equipment enabled the creation of a tourist route showing the whole day of a miner's work. During the tour, visitors go through a bathhouse, mechanical workshops, exhaust shafts, and to mining excavations. The bad technical condition of the buildings and the need to adapt them for safety issues forced the necessity of a complete renovation of the facilities. There were voices that said the place after renovation was too clean and aesthetic, and it was difficult to feel like in a real mine there. The objects and their equipment were preserved, but the genius loci of the place could not be saved.

Apart from the adaptation of old buildings, new facilities are also being built. Architects often reinterpret the local heritage in a creative way, using traditional materials (such as brick, steel, wood, court), types of construction (shed roof, half-timbered), or other references (e.g., red-painted window frames characteristic of worker settlements in Silesia). In the studied areas, the created objects fit well into the context of the place and are a kind of tribute to local heritage. One good examples is Przystań Bydgoszcz (Bydgoszcz Marina) - a new object in the shape of a wave breaking on the shore or a yacht floating on the water. It was covered with wood in the same color as the nearby half-timbered museum buildings on Wyspa Młyńska. The building received the World Leisure International Innovation Prize 2012 [49]. Besides positive examples there are also new buildings that can be defined as simulacra, using Jean Baudrillard's terminology: imitations that seem to be more authentic than the original objects [50]. Instead of adapting historic buildings, which would involve high costs, developers prefer to build new ones that pretend to have "an authentic industrial atmosphere." In this way the Księży Młyn district saw "lofts" built from scratch, contradictory to the idea of loft apartments (Figure 2). 

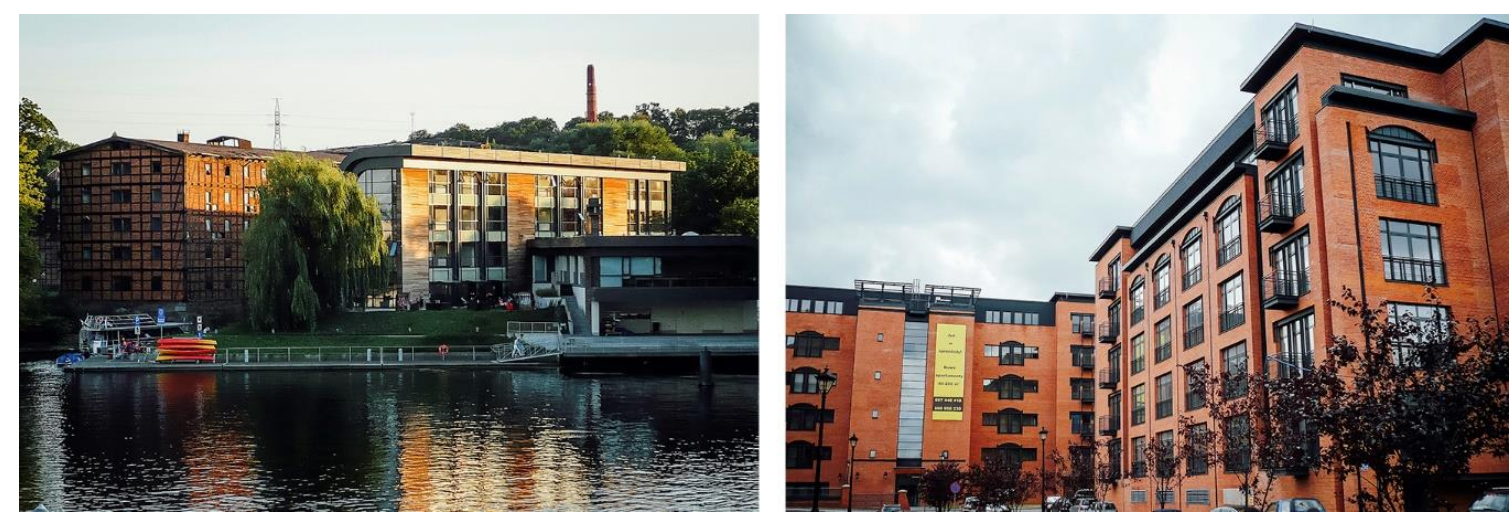

Figure 2. Przystań Bydgoszcz on Wyspa Młyńska (left). "Lofts" built from scratch in the Księży Młyn district (right). Author: Agnieszka Konior.

Another spatial issue is connected with heritage in the public space. The increasing quality of life in Poland means that more and more attention is paid to the quality of public spaces, so references to local heritage are often used to give them a specific character. Local history and its heroes can become an inspiration for creating topographic names. In the analyzed areas, streets, squares, bridges, or parks were named to honor local heritage (like Industrial Street, Towards the Mills Street, Mint Street, Spinning Street) and its protagonists (architects, local artists, or participants of historical events). An intrinsic feature of heritage is that it can never be fully transferred to future generations. Mindful of this, space administrators and the local community are trying to keep traces of the past in the form of tangible relics: factories' gates, railway sidings, carriages, hand pumps, factory and mine equipment. Moreover, local authorities seek to restore historical spaces (based on archival documents) by planting greenery or arranging street furniture. They justify the need for heritage preservation in the following manner:

However, what distinguishes a town is its specificity ... leaving the material elements that are associated with this identity is probably very important. [EX_05]

They moved in Zabłocie because they thought they were moving into a unique part of the city and that this postindustrial heritage would be there, and that they would simply not go to another mutation of the same café in a modern space but to an repurposed historical building where they will drink coffee in a place like nowhere else. [NGO_07]

Moreover, flats in this mill, for example, were more luxurious, maybe even "loft" apartments. And many people bought it as if aware that this is an interesting place, that it is also a postindustrial place. [CE_10]

Another quite obvious use of heritage is for remembrance purposes, like memorials or commemorative plaques. However, the research indicated that more and more examples are based on personal creativity and participatory activities. An example could be the installation on the walls of Nikiszowiec workers' housing: local associations in cooperation with designers prepared 360 bricks with the name and the age of each worker who died in the nearby mine. Other examples are mock-ups, mosaics, murals, site-specific art, or micro monuments located in different parts of cities, where residents are often involved in their design and construction. There also happen outdoor exhibitions, placed on special stands in windows of local shops or on walls. By situating them in public spaces, recipients can obtain information about the local heritage without barriers like difficult access to the object or entrance fees. Elements of cultural heritage can also be used to create public spaces conducive to the recreation of visitors. One example can be the Vistula Station park in Zabłocie, a district in Kraków, in the place of a train station of the same name. It was a bottom-up activity finally implemented by local authorities. There are elements referring to the history of the place, for example, 
movable benches placed on reconstructed railway tracks, not to mention playgrounds, bicycle tracks, and other recreation places also identified in the revitalized areas (Figure 3).
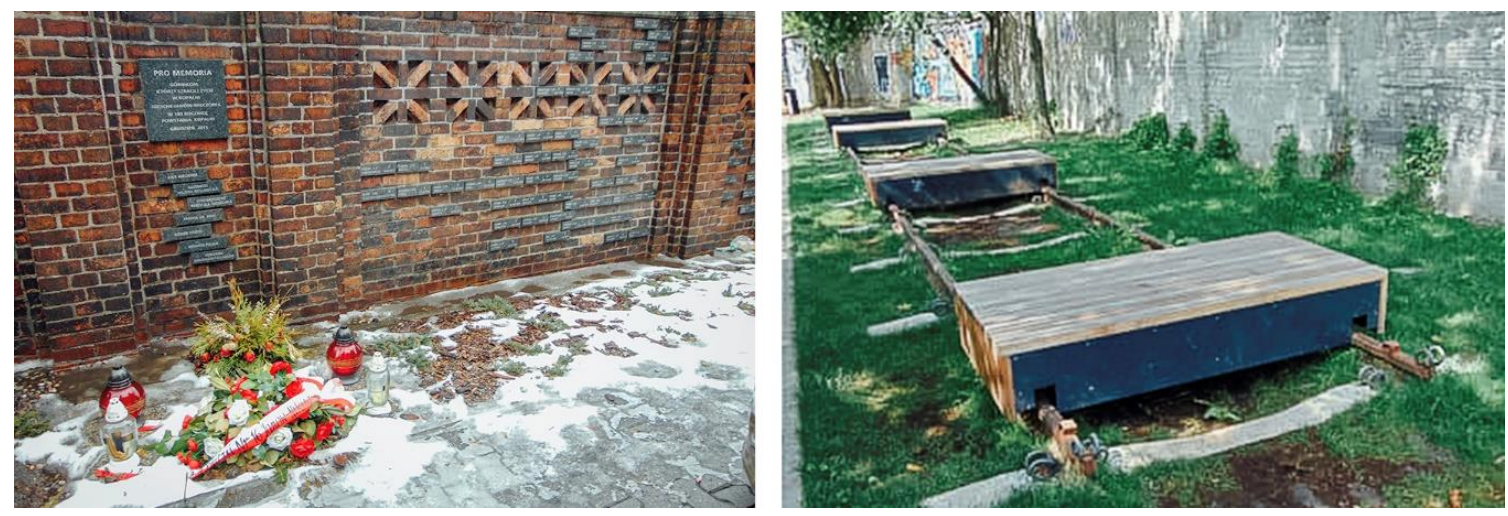

Figure 3. Bricks commemorating fallen miners in Nikiszowiec (left). Vistula Station park in Zabłocie district—benches placed on reconstructed railway tracks (right). Author: Agnieszka Konior.

\subsubsection{Social Dimensions}

Social revitalization is not only about preventing negative factors such as poverty, violence, addiction, or unemployment but also about supporting positive attitudes. In this case cultural heritage may be useful. However, it is a difficult task because the community might expect direct actions (e.g., subsidies) that give immediate results. Work with heritage in the social field is a long-term process, which often includes restoring the residents' self-confidence and pride to the place of residence, rebuilding or strengthening communities, shaping local identity and building a civil society in which all its members will feel responsible for joint ownership of the renewed space. Therefore, the key role is that of entities able to awaken in a community the need to discover its identity and make it aware of the value of heritage. In the scrutinized cases, these were representatives of cultural and education institutions, NGOs, local activists, experts, journalists, and even tourists. The use of social tools also helps to prepare the local community for changes, benefit from them, enable conflict resolution, and encourage involvement in the process of revitalization planning.

The analysis of events organized by various stakeholders in the areas under study indicated that one form of heritage use is the organization of lectures and presentations. It is a rather passive form of providing information, only slightly engaging the recipients, although some offer accompanying discussions and question sessions. However, expert lectures contribute not only to broadening recipients' knowledge but also to making them aware that their heritage is important; the fact that external researchers deal with it may cause the heirs to appreciate it more. An example can be the well-frequented series of lectures "Przystanek Nikiszowiec" ("Nikiszowiec Bus Stop"), during which experts from various fields talk about local history.

In each of the selected cases a museum operated or was planned for the near future. It seems to be the basic type of organization to deal with local cultural heritage. Most often these were historical museums (focused on industry or local history) or art museums. The desire to theatricalize exhibitions and increase interactions was evident. In this regard, it is worth mentioning an exhibition organized using participatory methods in Stara Kopalnia in Wałbrzych. The preparation process was as important as the final result. Under the care of museum workers, animators, artists, and former miners, pupils of local schools prepared an exhibition for which they chose exhibits themselves. The process of preparing the exhibition became a great opportunity for an intergenerational integration because young people had a chance to talk to mine employees about individual objects and the work in the mine in general. The result of these activities is the installation "W górniczym labiryncie" ("In a Miner's Maze"), which is included in the permanent exhibition. Museums are not only places of information about local heritage. Their functioning contributes to building a sense of pride among the residents, 
as they willingly bring their guests to show the place and describe the history of the area. Below are some examples from the interviews:

We clearly see that Wałbrzych inhabitants begin to feel proud of the fact that this is here, and they are bringing their friends from all of Poland to show them ... This is what we notice, especially in vacation periods like this one; masses of thirty- to forty-year-olds or more who proudly show their friends around, saying: "You go and do the sightseeing, and we will sit in Sztygarówka [Steiger's house], have a cup of tea and wait for you, it's alright". [CE_09]

People from Nikiszowiec come and bring their relatives ... And that I want to show you: "No, no, because I know everything here, because I have been here many times, but here I have family from Germany, I will tell everything." And they know more than I do, because I know everything from stories here. "We live here," that's cool. And it's cool that as soon as someone comes to someone, they immediately lead them to the museum. That they want to show that they have one in their district, because no other district actually has one. [CE_08]

By donating family collections, they show these institutions their trust, and they know that the employees will take good care of their belongings. Another type of exhibition is connected with art. Presentations of works resulting from plein-air painting in the area, local landscapes, industrial photography, and site-specific installations were organized. It seems evident that industrial heritage is an inspiration for artists. They focus on both consolidating the image of the place and referring to the industrial atmosphere of the area. They also use their own family stories and point to individual relationships with the place. Moreover, we should mention that industrial spaces are a great background for contemporary art exhibitions (paintings, sculptures, and installations).

Workshops are a form of activity that enables the integration of the local community. The goal is to transfer knowledge through play, deepen manual skills, get to know each other, spend time together, and introduce locals to the institution that organizes the event. Some of the workshops were intended for students and took place, for example, during museum lessons. During workshops dedicated to various groups, participants could learn about traditional craft and handicraft methods. The local heritage was creatively referred to using materials such as coal, glass, and ceramics, which were typically used in the industrial past of the region. Efforts were made to involve all senses, including the sense of taste: culinary workshops were a perfect opportunity to integrate, exchange recipes, jointly prepare and celebrate a meal. During "Maszketnik—spotkania ze śląska kuchnią" ("Goodies-An Encounter with Silesian Cuisine") older residents of the Nikiszowiec district showed young people how to cook traditional local dishes. It was an opportunity to talk about life in the district, also using the Silesian dialect.

Among the projects implemented in the studied areas, those based on oral history were especially popular. This kind of documentation allows people to capture local stories using polyphonic narratives. Oral stories can be used as one of the tools of social revitalization, which activates both the younger and the older generations, who witnessed history. One example is "Górnicze historie" ("Mining Stories"), implemented by Stara Kopalnia in Wałbrzych as part of the abovementioned project "W górniczym labiryncie." The task of the Wałbrzych school students was to interview members of their family about the working conditions in the mine. Interviews and stories created on this basis were posted on the project website [51]. The result of the work is to preserve local history and increase knowledge and interest in the past in the youngest generation.

A lot of recurring events and festivals were organized in the study area. Among them were the Night of Museums, open days, European Heritage Days, celebrations connected with cultural routes, flea markets, fairs, traditional holidays like Saint Barbara Day (the patron saint of miners). For example, Jarmark na Nikiszu (Fair in the Nikiszowiec District) has taken place since 2008. It started as a very small initiative, organized by the local community and an NGO to collect money for a video monitoring system. Over the years it has evolved into one of the largest Christmas markets in Silesia. What distinguishes it from others is that only confirmed craftspeople are allowed to sell 
their products there (in 2019 there were over 200 stalls [52]). Moreover, there is an accompanying program with performances of mining orchestras, local music bands, and sightseeing tours around the district. The organization is based on the volunteer work of residents, and the money collected during the event is allocated to the activities of a local NGO. Festivals and cyclical events based on local heritage are great opportunities to get to know given places for people who have not yet had the opportunity to visit them. They are offered numerous attractions, unavailable on a daily basis, often in a unique setting. The concentration of events at one time makes them less burdensome for residents, but it also becomes something unique and expected. They enable the integration of entities from various industries, for example, during the festival in Nikiszowiec local restaurants offer a special menu; there is also the possibility of visiting museums, galleries, and artists' studios beyond typical opening hours (Figure 4).
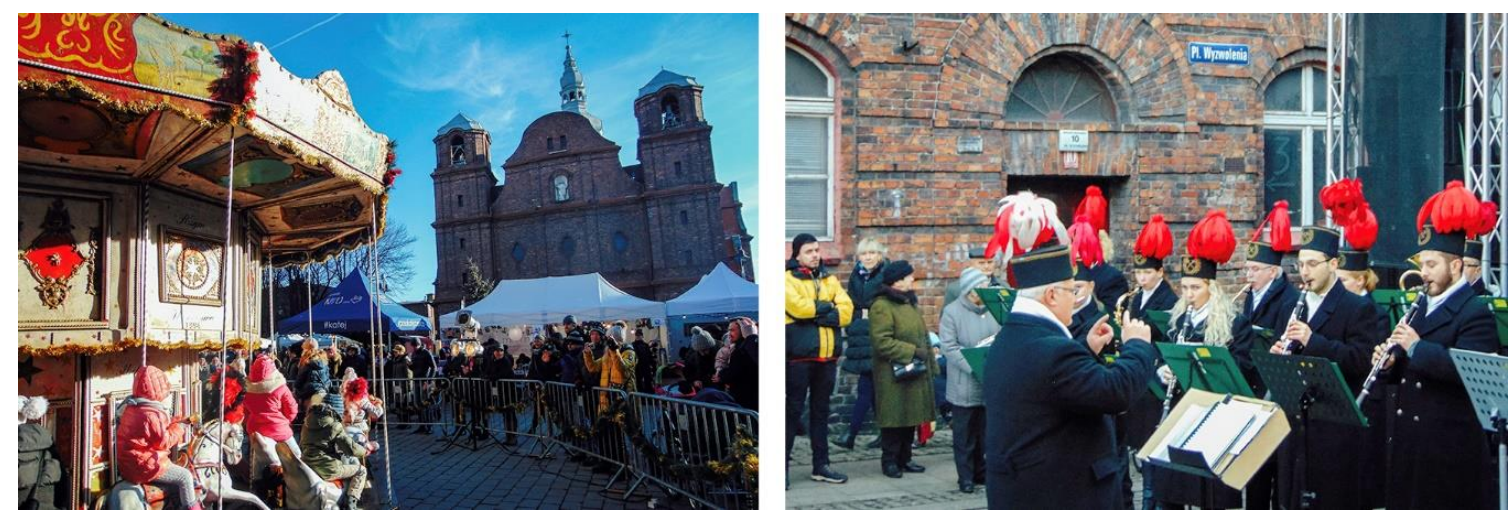

Figure 4. The Nikiszowiec District 2017. Author: Agnieszka Konior.

Cultural heritage is also becoming an inspiration for organizing other events that refer to it directly or indirectly. These include performances of dance groups, those using both traditional songs and ritual elements and contemporary dance shows inspired by the same tradition. An example can be the performance "WORK it OUT" organized by the European Industrial Heritage Route (e.g., in the Old Mine, Nikiszowiec District; both parts of the route). The dance was inspired by the movements of workers at the factory. Industrial heritage is also present in music, played by orchestras that once operated at the mines and contemporary musicians who create industrial music, inspired by the sounds of industrial production or using local dialects. Cinematography was another identified type of art that used local heritage. Documentary and feature films along with music videos were produced in the studied areas. Films presenting local heritage contribute to its popularization-the dissemination of knowledge about local history—and are also a source of pride for the local community.

\subsubsection{Economic Dimensions}

What is desirable as part of the revitalization process is the economic activation of the area, manifested through the creation of new enterprises. New jobs also appear in public institutions-including those related to culture and education-emerging in revitalized areas. Thanks to public investments, the snowball effect can result, influencing the creation of new enterprises. As part of the area's revitalization, the existing type of economy is also transformed from industrial to postindustrial, which — thanks to the use of the historic values of the place-can largely be based on the postindustrial tourism that has become increasingly popular in Poland.

Along with the increase in popularity of the analyzed areas and the accompanying increase in tourist traffic, the appeal addressed to different groups of visitors (tourists, one-day visitors, and local residents) is also expanding. It is clearly visible that the appeal is directed at cultural [53-55] rather than mass tourists. The addressed recipient is anticipated to have the basic knowledge of industrial heritage or is open enough to be interested in new, previously unknown topics. He or she wants to get to 
know the place in depth, in which local guides can be helpful, e.g., miners showing them around their former workplace or residents associated with the place for generations who know the local topics of interest. Themed tours were available in the tourist offers we analyzed, which make it possible to explore the area according to individual interests. Several trends clearly emerged, allowing us to conclude that they were part of the experience market [56]. The trends focused on the engagement and emotions of recipients, in which the following were distinguished: city games, questing, fictionalized tours (the guide or visitors were disguised in historical costumes; reconstruction groups were also involved). Efforts continue to make information about local heritage available to the widest possible public for self-use without a guide, and sometimes even without leaving one's home. Some offers are noncommercial or are available for a small fee. Among them, we distinguished audio guides, virtual reality tours, and mobile apps. Elements of oral history are also increasingly used; guided tours of a given place are not only transfers of facts but also stories filled with personal experiences. The interviewees explained why locality is important to them and what mission they follow in their activities:

[We do it] for people to come, see, listen to history, and that it is not a piece of wall ... That they would respect the place and appreciate it. [NGO_07]

[We plan to implement programs] related to fostering relationships among local entrepreneurs. This is very important to us. We are changing [from an NGO] into a business, so it is very important for us to build various types of brands that will be local brands. We seek to build these business relationship here in such a way so that it supports the development of the housing estate and does not cause various negative phenomena. This way ... [will be] balanced. [NGO_02]

Gastronomy points located in the studied areas, such as cafés, restaurants, and pubs, use the local cultural heritage in many ways. The first example of this is reference by the name. The owners refer to important persons associated with the place, past factories, the postindustrial character of the place, or-especially in the case of Silesia-the local dialect. References also appear in the interior design. Interior architects try to create or emphasize the industrial climate with the materials created and used here, such as steel, copper, brick, concrete, Corten steel. Installation components usually remain uncovered. Large-format historical and contemporary photographs, drawings, and maps appear on walls with images of industrial facilities. Souvenirs, antiques, and items found in antiques fairs are also part of the interior design (Figure 5). Moreover, local heritage can be used as an inspiration for waitresses' uniforms. References to the local cultural heritage are visible in the menu: not only regional cuisine but also "traditional" names given to modern dishes (for example a hot-dog is called the "hot-hammer"). In a separate category are local beers, sold or even produced locally. Brewed with traditional methods, the beers also bear brands that refer to local tradition. The Księży Młyn Brewery has in its line-up Cotton (pils), Spinning (porter beer), Satin (March), Silk (bock), Sateen (porter), and Textile (extra special bitter). The owners of cafes and restaurants take care of all the details, largely inspired by local heritage. This makes the visit not only a culinary but also an aesthetic experience. These facilities complement the sightseeing route with their design and menus. For the local community, they can be a sign that their own heritage can be the source of pride-and also of income.

Due to the development of the tourist market, more accommodation possibilities appear in the studied areas. These are both hotels and short-term rental apartments. Similar elements are used inside the hotels and apartments as in the cafés and restaurants: uncovered brick, historical and industrial pictures on the walls, antique furniture, a retro vibe. Historical elements are combined with modern equipment and design. A great attention to detail is visible, e.g., in kitchen equipment, but not all accommodation employs heritage potential. 

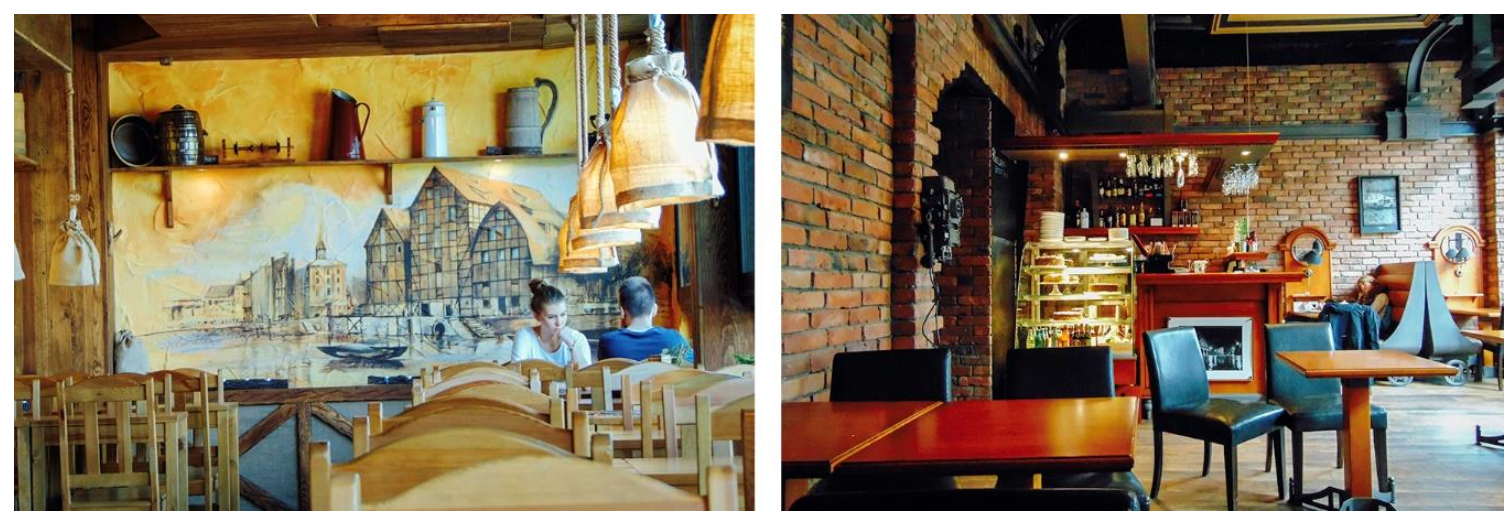

Figure 5. Examples of restaurant interiors in a postindustrial style. Author: Agnieszka Konior.

Most of the souvenirs offered in the studied areas are made on site by local artists and craftspeople, which are considered valuable. These are usually standard tourist products, such as postcards, magnets, or cups with images of local monuments. Sometimes local artists focus on one element, which is then reproduced, becoming a kind of brand (e.g., rose mosaic placed on a building in the Nikiszowiec district). One can also find creative products that use postindustrial history, such as "Sadza Soap" - soap in the shape of a lump of coal. Another example is jewelry made of coal or in an industrial style, mostly inspired by steampunk aesthetics. One of the artists said:

"I try to look for some inspiration here, some time ago I made a series of ceramics that was in some way inspired by such an industrial heritage, i.e., postindustrial Silesia. And this is such a steampunk series". [LE_04]

Products targeted at both tourists and residents are clothes (t-shirts, hats, backpacks, bags). We may also treat this as an element of internal marketing [57], not aimed at selling any products but at strengthening pride in the place of residence and the desire to manifest it through clothing. Sometimes it is also possible to create customized souvenirs: minting coins, burning ceramics, blowing glass figurines, making one's own t-shirts and bags. The above possibilities fully fit into the experience economy. Various types of guides can also be considered souvenirs. They are published both by commercial publishing houses, public institutions, and even NGOs with the participation of the local community (often being a documentation of oral history). Therefore, book guides can not only become a source of income and spread knowledge about the most important attractions of the place but also exist as a way of documenting heritage and integrating the local community.

A cultural route is the last identified way of using heritage resources in economic aspects. It can be defined as "a marked material route, connecting objects and places selected following a set thematization criterion, with unique and representative examples that illustrate the broadly defined cultural heritage of the region, communities, ethnic groups, national minorities or a nation" [58] (p. 76). The studied objects are included in international, national, regional, local, or urban routes. Moreover, routes running only through the examined districts are created. Cultural routes not only contribute to the increase in tourist traffic and redirect it to less popular places but can also be a medium of change in the region [58,59], enabling heritage preservation, increasing awareness of its importance, boosting the sense of local identity, and creating around it various types of activity. An example of such a multidimensional route was a project implemented by Stara Kopalnia in Wałbrzych. The project was implemented by volunteers from local schools and universities. Through field research, they identified objects to be included in routes of industrial heritage. In total, six routes and an interactive map were created [60]. The project not only contributed to the development of tourist appeal but also expanded the knowledge of its participants and may have increased the interest in local history. Cultural routes were treated not only as a tourist product but also as a tool of social change. 


\section{Discussion}

The Effects of Using Heritage in Postindustrial Revitalization Processes

Heritage resources were used in a variety of ways in the revitalization processes. The diversity of heritage uses resulted from selected objectives of an activity and the creativity of individual stakeholders. First of all, we should emphasize that not only tangible but also intangible heritage resources were used in the revitalization processes. The use of heritage meant not only the adaptation of historic buildings for new functions but also drawing on the achievements of previous generations in relation to both their goods and customs and the ideas behind them (e.g., innovation). Heritage-based urban revitalization processes had many benefits not only for spatial but also for social and economic aspects. We gathered them in Table 3 below.

Table 3. Benefits of heritage-based urban revitalization processes.

\begin{tabular}{|c|c|c|}
\hline Spatial Benefits & Social Benefits & Economic Benefits \\
\hline $\begin{array}{l}\text { - } \quad \text { monument preservation } \\
\text { the renovation and } \\
\text { adaptation of } \\
\text { historic buildings } \\
\text { an improvement of } \\
\text { housing standards } \\
\text { an increase in social and } \\
\text { cultural services } \\
\text { and activities } \\
\text { the improvement of the } \\
\text { quality of public spaces } \\
\text { the use of available resources } \\
\text { (sustainable } \\
\text { area development) }\end{array}$ & $\begin{array}{l}\text { - } \quad \text { the improvement of the } \\
\text { image of the area } \\
\text { - } \quad \text { place marketing } \\
\text { upholding or giving } \\
\text { character to the area } \\
\text { (genius loci) } \\
\text { - } \quad \text { the increase in the prestige } \\
\text { connected with living in } \\
\text { the area } \\
\text { - creating a reason to be a } \\
\text { proud member of } \\
\text { local community } \\
\text { building civil society } \\
\text { - } \quad \text { inspiring cultural and } \\
\text { - } \quad \text { social activities } \\
\text { strengthening bonds between } \\
\text { generations and ensuring } \\
\text { social cohesion } \\
\text { activating senior citizens } \\
\text { improving the quality of life }\end{array}$ & $\begin{array}{l}\text { an increase in the market } \\
\text { value of renovated historic } \\
\text { buildings and } \\
\text { their surroundings } \\
\text { an inspiration to } \\
\text { local entrepreneurs } \\
\text { - } \quad \text { maintaining traditional crafts } \\
\text { - } \text { the creation of new } \\
\text { job opportunities } \\
\text { the reduction in the scale of } \\
\text { migration to other } \\
\text { urban centers } \\
\text { the development of the local } \\
\text { tourist market }\end{array}$ \\
\hline
\end{tabular}

Revitalization resulted in the preservation of historic buildings that are now renovated and adapted to new needs. These were both residential buildings (the improvement of housing standards) and buildings adapted for social, cultural, or service purposes. Increasing room for service areas contributed to broadening the appeal for customers. The quality of public spaces was influenced by the renovation of historic buildings, the construction of new buildings that refer to the local character, and the creation of common spaces related to the local heritage. The reuse of available resources-both facilities and the revitalization of urban areas that prevents urban spillage-resulted in the sustainable development of the entire area.

We identified most benefits associated with the heritage-based revitalization processes in the social area. The revitalization of the studied examples changed their image: most of them were transformed from degraded pathological areas into attractive places to live and visit. Heritage was also used for the promotion of the scrutinized places. The activities related to the spatial and social spheres resulted in the emphasis on the character of the place, which is its distinguishing feature (genius loci). By using heritage, the local identity was reinforced. It also increased the prestige associated with living or staying in a given space. Thanks to joint actions, residents began to be proud of their place of residence, and they integrated well with each other. Concern for the surrounding space and common good resulted in the reinforcement of civic attitudes and civil society. 
Heritage was also an inspiration for sociocultural activities undertaken not only by public, private, and non-governmental organizations, but also by local activists. Participation in joint heritage-related activities (both private and public) helped to maintain social and intergenerational ties. Heritage-based actions also led to the activation of older people, which should become one of the priorities of local authorities in Poland in the face of the nationwide aging of the population. Thus, the use of heritage in the researched revitalization processes contributed to the improvement of the quality of life in many aspects.

Furthermore, heritage had an impact on the economic dimensions of the revitalization process. The adaptation of historic buildings to new purposes contributed to the increase in market value of buildings and their surroundings. Hence, heritage became the source of inspiration for local entrepreneurs, who created new products and services based on the specific heritage. This contributed to the protection of existing jobs and to the creation of new jobs related to both traditional professions and the creative industry. Finding employment opportunities in the place of residence reduced the number of migrations to other urban centers and stopped the processes of urban depopulation, as one of the interlocutors stated:

And besides: young people who escaped from here ... are more likely to return to something that has roots, which is associated with some tradition, a place where generations lived with other generations. This has such a force of attraction. It is difficult to return to a city that has no history, it is like hundreds or thousands of other cities. [CE_09]

The promotion of local heritage was also conducive to the development of the tourist market, which brought measurable profits for both private entrepreneurs and the public sector (e.g., in the form of taxes), which indirectly translated into an increase in the well-being of the entire local community.

In the examples examined above, the use of heritage brought positive effects and in most cases was used in a prudent manner, respecting the heirs. The only exception was Zabłocie, where a rapid gentrification process occurred: part of the heritage was destroyed against the protests of residents and NGOs. Due to the destruction of industrial monuments, many small companies from creative industries located there had to move. The investment pressure was too strong to stop the destruction, especially when the area was attractive and there was no preventive action by the local government (e.g., law or regulation). However, we should bear in mind that the revitalization process is extremely complex, and unfortunately, it is not easy to transform heritage in a way compatible with the perception of its heirs. This happens most often in cases of excessive commercialization caused by developing tourism. Furthermore, the use of heritage is always on the verge of authenticity: to make it easier to commodify, only some elements may be selected for the benefit of those elements easier to sell, for example, with the exception of difficult heritage. In general, the most common negative effect of revitalization is progressive gentrification, which causes severe social, economic, and spatial changes that exclude the legitimate heirs. However, we should remember that heritage can arouse strong and extreme emotions. Their management requires a sensible and subtle approach that does not exacerbate conflicts or negative emotions but allows for dialogue and constructive cooperation.

To summarize, cultural heritage can play a key role in the revitalization process of postindustrial areas, which affects their social, environmental, and economic dimensions. The above research allows us to state that the awareness of heritage's significance in the coming years may only increase, and revitalization processes based on cultural heritage in Poland will gain in popularity.

Author Contributions: Conceptualization, A.K., W.P.; methodology, A.K.; investigation, A.K.; resources, A.K., W.P; data curation, A.K., W.P.; writing—original draft preparation, A.K., W.P.; writing—review and editing, W.P. All authors have read and agreed to the published version of the manuscript.

Funding: This research was funded by the Department of Management and Social Communication, Jagiellonian University, under the grants: Rola aktywności kulturalnej i lokalnego dziedzictwa w procesach rewitalizacyjnych (grant number: K/DSC/002817); Zarządzanie dziedzictwem w procesie rewitalizacji terenów poprzemysłowych (grant number: K/DSC/003617).

Conflicts of Interest: The authors declare no conflict of interest. 


\section{References}

1. Forum Rewitalizacji-Definicje. Available online: www.forumrewitalizacji.pl/artykuly/15/38/Rewitalizacjapodstawowe-pojecia (accessed on 14 March 2020).

2. Balsas, C. Entrepreneurial Urban Revitalization. In Entrepreneurship and the industry life cycle; Cubico, S., Favretto, G., Leitão, J., Cantner, U., Eds.; Springer: New York, NY, USA, 2018; p. 330, ISBN 978-3-319-89335-8.

3. Gerber, P. Ochrona dziedzictwa przemysłowego w Polsce. Doświadczenia Muzeum Przemysłu i Kolejnictwa na Śląsku. In Rewitalizacja Dziedzictwa Przemysłowego = Industrial Heritage Revitalization; Kołodziej, J., Ed.; Wyższa szkoła Gospodarki w Bydgoszczy; Instytut Historii Nauki Polskiej Akademii Nauk: Bydgoszcz/Warszawa, Poland, 2011; ISBN 978-83-86062-04-1.

4. Frąckiewicz, L. Wykluczenie, rewitalizacja, spójność społeczna: Praca zbiorowa; Ślask: Katowice, Poland, 2004; ISBN 978-83-918320-0-4.

5. Jadach-Sepioło, A. Rewitalizacja miast w dokumentach strategicznych w Polsce. Odniesienia do projektu krajowej Strategii Rozwoju Regionalnego 2010-2020: Regiony, miasta, obszary wiejskie. In O budowie metod rewitalizacji w Polsce-aspekty wybrane; Skalski, K., Ed.; Monografie i Studia Instytutu Spraw Publicznych Uniwersytetu Jagiellońskiego: Kraków, Poland, 2010; pp. 11-28.

6. Skalski, K. Rewitalizacja w Polsce po roku 2009 a rozwój dydaktyki dla zarządzania tym procesem. In $O$ budowie metod rewitalizacji w Polsce - aspekty wybrane; Skalski, K., Ed.; Monografie i Studia Instytutu Spraw Publicznych Uniwersytetu Jagiellońskiego: Kraków, Poland, 2010; pp. 47-64.

7. Noworól, A.; Noworól, K. Rewitalizacja obszarów miejskich jako wehikuł rozwoju lokalnego. Studia KPZK 2018, 177, 129-144. [CrossRef]

8. Kołacz, P.; Wielgus, P. Przepis na rewitalizację; Fundacja dla Uniwersytetu Kazimierza Wielkiego: Bydgoszcz, Poland, 2015.

9. Ustawa o rewitalizacji. Available online: http://prawo.sejm.gov.pl/isap.nsf/download.xsp/WDU20150001777/ U/D20151777Lj.pdf (accessed on 14 May 2020).

10. Jarczewski, W.; Kuryło, M. Rewitalizacja terenów powojskowych. In Przestrzenne aspekty rewitalizacji-śródmieścia, blokowiska, tereny poprzemysłowe, pokolejowe, powojskowe; Jarczewski, W., Ed.; Instytut Rozwoju Miast: Kraków, Poland, 2010; pp. 260-266, ISBN 978-83-89440-51-8.

11. Großewinkelmann, J. Care of industrial and technical collections. In Industrial Heritage Re-Tooled: The TICCIH Guide to Industrial Heritage Conservation; Douet, J., Ed.; Routledge: New York, NY, USA, 2012; p. 189, ISBN 978-1-62958-203-0.

12. The Niznhny Tagil Charter for the Industrial Heritage, 17 July 2003. In Industrial Heritage Re-Tooled: The TICCIH Guide to Industrial Heritage Conservation; Douet, J. (Ed.) Routledge: New York, NY, USA, 2012; p. 236, ISBN 978-1-62958-203-0.

13. Stuart, I. Identifying industrial landscapes. In Industrial Heritage Re-Tooled: The TICCIH Guide to Industrial Heritage Conservation; Douet, J., Ed.; Routledge: London, UK, 2012; p. 48, ISBN 978-1-62958-203-0.

14. Affelt, W. Dziedzictwo techniki, jego różnorodność i wartości. Kurier konserwatorski 2009, 5, 6.

15. Handszuh, H. Założenia konferencji. In Nowe otwarcie dla turystyki-niematerialne dziedzictwo przemysłowe: XIII Międzynarodowa Konferencja a temat Turystyki Dziedzictwa Przemysłowego; Urząd Miejski w Zabrzu: Zabrze, Poland, 2016; p. 12, ISBN 978-83-945133-0-6.

16. Cossons, N. Why preserve the industrial heritage? In Industrial Heritage Re-Tooled: The TICCIH Guide to Industrial Heritage Conservation; Douet, J., Ed.; Routledge: New York, NY, USA, 2012; pp. 7-11, ISBN 978-1-62958-203-0.

17. Kronenberg, M. Wpływ zasobów dziedzictwa przemysłowego na atrakcyjność turystyczna miasta: Przykład Łodzi; Wydawnictwo Uniwersytetu Łódzkiego: Łódź, Poland, 2013; ISBN 978-83-7525-769-4.

18. Kronenberg, M. Turystyka dziedzictwa przemysłowego - próba sprecyzowania terminologii. In Dziedzictwo przemysłowe jako strategia rozwoju innowacyjnej gospodarki: IV Międzynarodowa Konferencja Naukowo Praktyczna; Burzyński, T., Ed.; Śląska Organizacja Turystyczna: Agencja Artystyczna PARA: Katowice, Poland, 2007; p. 35, ISBN 978-83-926170-4-4.

19. LeDuff, C. Detroit: Sekcja zwłok Ameryki; Wydawnictwo Czarne: Wołowiec, Poland, 2019; ISBN 978-83-8049-856-3.

20. Tweed, C.; Sutherland, M. Built cultural heritage and sustainable urban development. Landsc. Urban Plan. 2007, 83, 62-69. [CrossRef] 
21. Gerner, M. Managing Cultural Sustainability: Safe Haven, Cultural Property, and Sustainability in Best Practice. In Cultural Heritage and International Law; Lagrange, E., Oeter, S., Uerpmann-Wittzack, R., Eds.; Springer: Cham, Switzerland, 2018; pp. 175-208, ISBN 978-3-319-78788-6.

22. Erlewein, S.-N. Culture, Development and Sustainability: The Cultural Impact of Development and Culture's Role in Sustainability. In Going Beyond; Albert, M.-T., Bandarin, F., Pereira Roders, A., Eds.; Springer International Publishing: Cham, Switzerland, 2017; pp. 85-97, ISBN 978-3-319-57164-5.

23. Council of Europe Framework Convention on the Value of Cultural Heritage for Society (Faro Convention). Available online: https://www.coe.int/en/web/conventions/full-list/-/conventions/rms/0900001680083746 (accessed on 14 March 2020).

24. Al-Zo'by, M. Culture and the politics of sustainable development in the GCC: Identity between heritage and globalisation. Dev Pract. 2019, 29, 559-569. [CrossRef]

25. Bizzarro, F.; Nijkamp, P. Cultural Heritage and Urban Revitalization: A Meta-Analytic Approach to Urban Sustainability. In Evaluation in Planning; Lichfield, N., Barbanente, A., Borri, D., Khakee, A., Prat, A., Eds.; The GeoJournal Library; Springer: Dordrecht, The Netherlands, 1998; volume 47, pp. 193-211, ISBN 978-90-481-5070-0.

26. Smith, B. Investing in heritage: A guide to successful urban regeneration; European Association of Historic Towns and Regions (EAHTR): Norwick, UK, 2007; ISBN 978-0-9557415-0-0.

27. Said, S.Y.; Zainal, S.S.; Thomas, M.G.; Goodey, B. Sustaining old historic cities through heritage-led regeneration. WIT Trans. Ecol. Environ. 2013, 179, 267-278.

28. Tomback, D.; Brennan, T.; Campbell, R.; Wheldon, A.; Oliva, L.; Cartwright, V.; Lock, G. Heritage Works. The Use of Historic Buildings in Regeneration. A Toolkit of Good Practice. 2013. Available online: https:/historicengland.org.uk/images-books/publications/heritage-works/ (accessed on 12 December 2018).

29. Great Britain, Parliament, House of Commons, Local Government and the Regions Committee. The Role of Historic Buildings in Urban Regeneration: Report, Together with Formal Minutes, Oral and Written Evidence; House of Commons the Stationary Office: London, UK, 2004; ISBN 978-0-215-01903-5.

30. Pawlak, C. Miasto w mieście. In Łódź-Księży Młyn: Historia ludzi, miejsca i kultury.; Fuchs, E., Ed.; Muzeum Sztuki w Łodzi, Rezydencja "Księży Młyn": Łódź, Poland, 1998; pp. 11-20, ISBN 978-83-906130-2-4.

31. Salm, J. Wokół Księżego Młyna—architektoniczne i urbanistyczne przemiany fabrycznej jurydyki. In Księży Młyn; Barberska, D., Pytlas, S., Salm, J., Zielińska, A., Eds.; Urząd Miasta Łodzi: Łódź, Poland, 1998; pp. 43-87.

32. Hanzl, M. Księży Młyn-uwarunkowania urbanistyczne i społeczne - diagnoza. In Nasz Księży Młyn. Raport; Hanzl, M., Ed.; Towarzystwo Opieki nad Zabytkami Oddział w Łodzi: Łódź, Poland, 2011; pp. 10-76.

33. Piątek, E. Historia kopalni węgla kamiennego "Julia” (Fuchs, Biały Kamien, Thorez). Available online: http://www.boehm-chronik.com/bergbau/julia.pdf (accessed on 15 November 2017).

34. Strzałba, K. Tożsamość regionalna Wałbrzyszan. In Wałbrzych: Miasto poszukiwaczy; Filimowska, A., Krygowska, N., Eds.; Wydawnictwa AGH: Kraków, Poland, 2016; pp. 13-20, ISBN 978-83-7464-820-2.

35. Piątek, E.; Piątek, Z. Zapis dziejów dolnośląskiego górnictwa węglowego 1434-2000. Available online: http://www.boehm-chronik.com/bergbau/gorn1434-2000.pdf. (accessed on 15 November 2017).

36. Loose, I. Renowacja obiektów dziedzictwa kulturowego na terenie Wyspy Młyńskiej w Bydgoszczy; Urząd Miasta Bydgoszczy: Bydgoszcz, Poland, 2015.

37. Licznerski, A. O dawnych wodnych młynach bydgoskich. Kalendarz Bydgoski; Towarzystwo Miłośników Bydgoszczy: Bydgoszcz, Poland, 1974; pp. 53-56.

38. Filinger, D. Tygle z badań archeologicznych prowadzonych na terenie dawnej Mennicy Bydgoskiej. In Materiały do dziejów kultury i sztuki Bydgoszczy i regionu; Wysocka, A., Łbik, L., Eds.; Wojewódzki Ośrodek Kultury i Sztuki "Stara Ochronka" w Bydgoszczy: Bydgoszcz, Poland, 2013; volume 17, pp. 11-17.

39. Obremski, M. Mennica Bydgoska, rekonstrukcja i współczesne zagospodarowanie. In 400-lecie mennicy bydgoskiej 1594-1994: Referaty z sesji numizmatyczej 23 września 1994; Kiepuszewski, J., Maciuk, P., Eds.; Agencja Wydawniczo-Poligraficzna Progres: Bydgoszcz, Poland, 1994; ISBN 978-83-86199-15-0.

40. Tutak, M. Opowieść o Podgórzu: W stulecie połaczenia z Krakowem: Historia miasta w zbiorach Domu Historii Podgórza; Wydanie, I., Ed.; Dom Kultury “Podgórze”: Kraków, Poland, 2014; ISBN 978-83-64704-00-0.

41. Sokólska, K. Spacer przemysłowy. In Zabłocie: Przewodnik; Ciepły, G., Ed.; vis-à-vis/Etiuda: Kraków, Poland, 2014; pp. 47-49, ISBN 978-83-7998-010-9. 
42. Lulewicz, D. Żelazne zaułki Zabłocia, czyli spacer kolejowy. In Zabłocie: Przewodnik; Ciepły, G., Ed.; vis-à-vis/Etiuda: Kraków, Poland, 2014; pp. 61-68, ISBN 978-83-7998-010-9.

43. Gorgoń, J.; Starzewska-Sikorska, A.; Korcz, M.; Owczarska, I. Lokalny Program Rewitalizacji Zabłocia; Instytut Ekologii Terenów Uprzemysłowionych: Katowice, Poland, 2011.

44. Matuszek, P.; Tofilska, J.; Złoty, A. Nikiszowiec, Giszowiec i inne osiedla Katowic; Drukarnia Archidiecezjalna: Katowice, Poland, 2008; ISBN 978-83-7593-005-4.

45. Tofilska, J. Nikiszowiec 1908-2008: Z dziejów osiedla i parafii; Muzeum Historii Katowic: Katowice, Poland, 2009; ISBN 978-83-87727-84-0.

46. Kopalnia Węgla Kamiennego Wieczorek. Available online: www.khw.pl/firma/kwk_wieczorek.html (accessed on 1 May 2018).

47. Tofilski, M. Wpływ form przestrzennych na lokalną tożsamość mieszkańców górnośląskich osiedli Giszowca i Nikiszowca. Pogranicze. PPBS 2017, 1, 27-48. [CrossRef]

48. Dragićević Šešic, M.; Stojković, B. Kultura: Zarzadzanie, animacja, marketing; Narodowe Centrum Kultury: Warszawa, Poland, 2010; ISBN 978-83-61587-41-5.

49. World Leisure Innovation Prize. Available online: https://www.worldleisure.org/wlo2019/wp-content/ uploads/2019/05/wlo_InnovationPrize_20170210.pdf (accessed on 12 April 2020).

50. Baudrillard, J.; Królak, S. Symulakry i symulacja; Wydaw Sic!: Warszawa, Poland, 2005; ISBN 978-83-88807-79-4.

51. Juraszek, K. Stara Kopalnia-Górnicze opowieści. Available online: https://starakopalnia.pl/projekt/wgorniczym-labiryncie/gornicze-opowiesci-2/ (accessed on 17 December 2018).

52. Jarmark na Nikiszu. Available online: https://www.facebook.com/JarmarkNaNikiszu (accessed on 19 January 2020).

53. Jędrysiak, T. Turystyka kulturowa; Polskie Wydawn. Polskie Wydawnictwo Ekonomiczne: Warszawa, Poland, 2008; ISBN 978-83-208-1759-1.

54. Buczkowska, K. Turystyka kulturowa: Przewodnik metodyczny; Akademia Wychowania Fizycznego: Poznań, Poland, 2008; ISBN 978-83-88923-99-9.

55. Mikos von Rohrscheidt, A. Turystyka kulturowa: Fenomen, potencjal, perspektywy; Wydawnictwo KMB Druk: Gnieźnieńska Wyższa Szkoła Humanistyczno-Menedżerska Milenium: Gniezno, Poland, 2008; ISBN 978-83-61352-00-6.

56. Kostera, M. Zarządzanie na rynku doznań. In Nowe kierunki w organizacji i zarzadzaniu: Organizacje, konteksty, procesy zarzadzania; Glinka, B., Kostera, M., Eds.; Wolters Kluwer: Warszawa, 2016; pp. 399-413, ISBN 978-83-8092-098-9.

57. Varey, R.J.; Lewis, B.; Lewis, R. Internal marketing: Directions of management; Routledge: London, UK, 2000; ISBN 978-0-415-21317-2.

58. Bogacz-Wojtanowska, E.; Gaweł, Ł.; Góral, A. Szlaki kulturowe jako medium zmian w kulturze; Stowarzyszenie Gmin i Powiatów Małopolski: Kraków, Poland, 2016; ISBN 978-83-65644-19-0.

59. Gaweł, Ł. Szlaki dziedzictwa kulturowego: Teoria i praktyka zarzadzania; Wydawnictwa Uniwersytetu Jagiellońskiego: Kraków, Poland, 2011; ISBN 978-83-233-3187-2.

60. Stara Kopalnia-szlaki. Available online: https://starakopalnia.pl/mapa/ (accessed on 30 August 2018).

(C) 2020 by the authors. Licensee MDPI, Basel, Switzerland. This article is an open access article distributed under the terms and conditions of the Creative Commons Attribution (CC BY) license (http://creativecommons.org/licenses/by/4.0/). 